\title{
Whom to Vote? Socio-Psychological Factors Influencing Voting Behavior in Rural Punjab, Pakistan
}

\author{
* Dr. Akhlaq Ahmad, Assistant Professor (Corresponding Author) \\ ** Dr. Mazhar Iqbal Bhatti, Assistant Professor \\ *** Dr. Farhan Navid Yousaf, Associate Professor
}

\begin{abstract}
Voting is the most common and effective way of political participation across the globe. Voting substantiates voters' will and decides the fate of the country. Voting signifies that voters are informed and responsible citizens and showing their interest in state and its matters. It is, however a very complex phenomenon. Different social, economic, institutional, political, situational, and personal factors are considered essential to elaborate voting behavior. The present research includes these factors to find out which factor/s explains the best in rural areas of the Punjab, Pakistan. For this research 241 voters were recruited from a rural constituency of district Jhang. Linear regression analysis was run for the analysis. Findings bring forth that Baradri (caste group) explains $72 \%$ variation in voting behavior followed by the influence of the family i.e. 20\%. Personality attributes, religious affiliation (sect), political campaign, and peer suggestions were somehow significant factors. However, sympathy with and experience of the candidate in politics were not statistically significant in this research. The study confirms that being a traditional society, caste group affiliation is more powerful in deciding whom to vote than other factors. Voters feel pressurized by their caste groups and respective families while deciding their votes.
\end{abstract}

Keywords: Determinants; Voting Behavior; Caste Group; Family Influence; Rural Punjab Introduction

Voting is the most common and effective way of political participation. It substantiates that through elections; the voters will decide the fate of the country and exercise their choices. It is a way to employ the power to accept and/or reject candidate/political party. It is a powerful tool to make leaders/political parties accountable for their doings. Voting endorses the allegiance to a political regime with its existing policies, plans, and programs. In a democratic system, voting has increasingly become a significant area of research. However, it is a very complex phenomenon. Voting and voting behavior research has identified Economic, institutional, political, situational, and personal factors very important to predict, determine and/or influence the voters their voting behaviors (Dubois, 2007; Lewis-Beck \& Stegmaier, 2008; Akhtar \& Sheikh, 2014; Shin \& Lee, 2017). To understand voting and voting behavior different theoretical streams like sociological, psychological, and rational choice help a lot. Determinants, factors, choices, and influences vary considerably with the political system, political culture, and political socialization of voters, political parties, challenges, and geography. The social setting of a society/state is also very crucial to under voting and voting behavior.

Pakistani political system is under the stronghold of caste, feudalism, religion, race, and ethnicity. Rural-urban divide is promoting, and perpetuating the political cleavages in the country. Caste, religion, race, ethnicity, and family loyalties are somehow, deciding factors in politics and election, however leadership, political party affiliation, political campaign, the competence of candidate, and political promises and their fulfilment are very important in urban areas (Kanwal, Shahid \& Naeem, 2016; Muhammad \& Hassan, 2016; Bashir \& Khalid, 2019). This research article took all of the above factors and sees which of the factors are affecting voting behavior in the rural

\footnotetext{
* Department of Sociology, International Islamic University, Islamabad Email: akhlaq.ahmad@iiu.edu.pk

** Department of Psychology, International Islamic University, Islamabad Email: mazhar.iqbal@iiu.edu.pk

*** Institute of Social and Cultural Studies, University of the Punjab, Lahore Email: drfarhan.iscs@ @u.edu.pk
} 
setting of the Punjab province in Pakistan hence, claiming the contribution in the current scholarship on voting behavior in rural areas.

\section{Objective of the Study}

1. To investigate factors affecting voting behavior of voters in the rural areas of Punjab

\section{Research Question}

$>\quad$ What are the social, psychological, cultural, and political factors affecting voting behavior of

\section{Review of Literature} voters in the study area

Personal attributes of the candidate like honesty, integrity, and/or commitment are the important factors in determining voting behavior. Voters take these personal attributes of the candidate serious to evaluate the political ambitions and skills. Candidates with honesty and religious outlook are liked by the voters (Giri, 2016). Candidate having charisma in the personality can attract the voters in the election (Akhatr \& Sheikh, 2014). Personal attributes play a very important role in the local government elections where the voters have acquaintances with candidates (Asian Survey, 2009). Personal commitment, solidarity, interest, and feeling of citizenship are very crucial factors enhancing voting (political participation) behavior (Kurtbas, 2015). Political parties always look for the candidate/s having very repute in the constituency and know by the charisma of personality or personal traits. However, a stream of researchers has found demographic and social factors like age, gender, education, ethnicity, religion, etc. very much vital in determining voting behavior see e.g. (Lazarsfeld et al.,, 1944; Carras, 1987; Verba et al., 1995; Rajesh, 1999; Sekhon, 2000; Asian Survey, 2009; Shahwar \& Asim, 2012; Giri, 2016).

Baradri (Caste group) is centuries old social organization of subcontinent (Pakistan and India). Baradri sets rules for every aspect of a social life right from birth till death including politics. It has become an integral part of politics and determines the fate of political decisions (Kamal, 2012; Ahmad \& Hussain, 2013). Baradri has not only become the prominent feature of politics in rural areas but it is also very crucial in urban areas (Rumi, 2009). Voters consider Baradri important of all others' political behaviors and prefer only those political parties representing their own Baradri (Andrew, 1999). Caste-based kinship, family bonds, and community relationships are also very central to determine voting behavior (Wilder, 1999; Mughees, 2006). Baradri plays a very fundamental role in local level elections than the national (Rajesh, 1999). The caste system is very crucial for voting and many politicians are only relying upon their caste groups for votes in elections (Carras, 1987; Bashir \& Khalid, 2019). The caste group is a very much decisive factor in politics in rural areas of Punjab.

Another important factor contributing to voting behavior is a political campaign. Planed and comprehensive political campaigns influence the voting behavior of voters. Political parties/candidates are coming up with innovative and novel campaigns to attract voters in rural and urban areas (Weiss, 2009). Political campaigns provide political parties to present their ideology and performance. It also helps political parties to show their manifestoes (Trent \& Friedenberg, 2008). Political parties differentiate them from other political parties and show their plans through campaigns (Smith, 2000). The manifesto of a political party is a face of the political party and can positively influence voters. Political campaigns are a very important source of taking manifesto to voters in an effective way (Askari, 2002). Campaigns mobilize workers as well as voters. Different forms and techniques of political campaigns encourage party workers' commitment and influence voters in favor of a political party (Shaheen, 2004; Bike, 2012). A comprehensive election campaign can guarantee the success of a candidate/party (Usman et al.,, 2013). Political promises during campaigns also influence voting behavior and voters generally trust these promises (Arrow, 1986; Persson \& Tabellini, 2000; Naurin, 2011). Party affiliation is also an important factor in voting behavior (Campbell et al.,, 1960; Dalton, Burklin \& Drummond, 2001).

The role of a family is very much important in shaping up the attitudes of the children including the political. It has been found that adolescents who discuss political issues with parents participate in the range of political activities and are enthusiastic to caste vote (Andolina et al., 2003; Torney-Purta et al., 2001). The youth realized these discussions very helpful. Youth engaged in discussions with their parents regarding different political issues and saw their parents are active in politics are found to be more participants in political activities including voting (Verba, Schlozman \& 
Brady, 1995). Young person grew up in family having an environment of political discussion within the home were more active in volunteering, voting, and participate in other political activities than those who do not have an environment like that (Andolina et al., 2003). Other networks like friends, neighbors also contribute immensely to predicting voting behavior. Voters rely on the information provided by family, friends, and neighbors regarding the election (Robinson, 1976). Friends encourage and persuade one another to go to poll the vote and support the particular candidate (Huckfeldt \& Sprague, 1991; McClug, 2004).

The involvement of money in the electoral process is an integral component all over the world and particularly in developing and underdeveloped regions like Africa and Asia. A vast majority of the population lives in the crunches of poverty and is largely attracted by money. Politicians buy votes for money and/or gifts (Dubois, 2007; Akhtar \& Sheikh, 2014). Money is also used in the form of provision of missing facilities, gifts, lavish lunches, and dinners for voters. Candidates use conspiracies against the opponent candidate or political party, spread rumors, and sometimes tailor fake, weird, and /or immoral scandals and public these through print and electronic media (Sheikh, Bokhari \& Naseer, 2015). All these actions intend to malign the integrity and personality traits of the opponent candidate.

Situational factors like timing of election or context in which the elections are taking place become very crucial. Voters under the influence of some incidence/ context vote for the party and/or candidate, they do not like otherwise. The assassination of a political leader in a terrorist attack in Khyber Pakhtunkhwa in 2018 helped her wife to contest and win the election. The voters were under the strong influence of context and were more sympathetic.

Religion/religious sects are very important in shaping up the political behavior of people in rural areas in Punjab. Religious adherence is very common in people and they are emotionally very much associated with religion and/or religion-related places, persons, and/or practices. Religious leaders including Pirs (custodian of shrine/s) are very influential in politics and they directly participate in politics or back some party or candidate in their respective constituency. Their influence in rural areas is very much visible (Bashir \& Khalid, 2019). The social organization of a society uniquely contributes to shape and/or affect behaviors including political and voting. Socio-cultural landscapes of rural areas denote a strong hold and influence of religion, ethnicity, caste, and feudalism (Sheikh, Bokhari \& Naseer, 2015).

The review of the current literature encompassed all theoretical explanations and their inherent components. It also covered the factors influencing voting behavior in urban/modern states. The literature cited detailed the experiences of different segments and regions to have a better ground to test the assumption/s in rural areas of Punjab, Pakistan.

\section{Theoretical Explanation}

Dominantly, voting behavior is explained within three theoretical strands like sociological, psychological, and rational choice schools of thought. Proponents of the sociological school of thought ascertained that the social and political environment of a voter is very important in shaping up voting behavior and influence whom to vote (Heywood, 2002). Socialization is believed to be the instrument of inculcation of political values and preferences and family being the primary agent (Sarlamanov \& Jovanoski, 2014). The sociological school of thought points out that income, occupation, area of residence, education, age, gender, caste, and family are very important factors determining voting behavior.

The psychological model emphasized on the motivational factors that lead a voter to vote. Proponents of the psychological model consider political parties, political issues, and political candidates are the most important objects to decide the vote (Bartels, 2002). Voters get inspiration from the agenda of a political party to vote. The voters feel motivated to solve the issues of the community, locality, or country. Candidate/s with their interpersonal skills and characteristics inspire and motivate the voters to vote for them.

While rational choice theory explained voting behavior in terms of rationality. The voters are profit maximizers and decide on the bases of the best available resource. They evaluate the profits and losses and go with the preferred benefits. Voters generally vote for the political party or candidate with the best programs to offer and that meet the preferences of voters (Anderson \& Heath, 2003). This research includes all the dimensions derived from the above theoretical underpinnings in the tool 
of data collection to see which theory/ies are better explaining voting behavior in the study area. This research for the first time combined all three theoretical approaches in a study.

\section{Materials \& Methods}

\section{Participants}

For this research 241 voters (registered) living in rural areas of Tehsil Jhang were recruited through simple random sampling. The age of the respondents ranged from $18-45$ years and above. Married participants were $73 \%(n=174)$ followed by $25 \%(n=60)$ single, $.8 \%(n=02)$ widows and $1.7 \%(n$ $=04)$ were divorced. A good majority of the participants $(57.5 \%, n=138)$ were educated up-to graduation level, where $(26.7 \%, n=64)$ were graduate and above and $(16 \%, n=38)$ were illiterate. The family system of the participants was predominantly the joint family system $(73 \%, n=175)$. Monthly household income ranges from Rs. 5000- $25000(70 \%, n=168)$.

Overall, $(22.5 \%, n=54)$ participants were affiliated with different political parties in various capacities; and, $77.5 \%(n=186)$ participants were not affiliated with any political party. All of the participants of this research cast votes during the last election held in 2018.

\section{Procedure}

Male enumerators conducted interviews with the participants. The participants were briefed about the purpose of the research, utilization of the data, and other formalities associated with this research. They were also asked for their consent to complete the interviews. Participants were asked if they do not want to continue the interviews they can do that. After the informed consent of the participants, interviews were conducted. The participants were not paid for their time. The enumerators assured them of the confidentiality of the information provided by them.

\section{Measures}

This study utilized different measures i.e. Personal attributes has 6 items with alpha reliability .92; Family influence has 5 items with alpha reliability .86; Baradri (caste group) influence has 7 items with alpha reliability .90; Peer pressure has 4 items with alpha reliability .84; Sect influence has 6 items with alpha reliability .90 ; Political campaign has 4 items with alpha reliability .87; Sympathy has 2 items with alpha reliability .78; Work experience has 4 items with alpha reliability .90 and Voting behavior has 3 items with alpha reliability .76. All the scales were measured on four-point Likert type scale where 4 shows strongly agree, 3 denotes agree, 2 represents disagree, and 1indetifies strongly disagree respectively. Overall, all the scales/subscales used in this research meet the designated/ approved alpha reliability range. The measures utilized were pre-tested. Randomly sampled 30 respondents were selected for pre-testing of the tool of data collection. The tool was finalized after the incorporation of required, necessary changes.

\section{Results}

Simple linear regression to see the influence of independent variables on Voting Behavior

\begin{tabular}{lcccc}
\hline $\begin{array}{l}\text { Variables } \\
\text { (Independent) }\end{array}$ & Beta & $\mathrm{R}^{2}$ & Adj. $\mathrm{R}^{2}$ & P. Value \\
\hline Baradri (caste group) & 0.848 & 0.719 & 0.718 & $<0.0001^{* * *}$ \\
Family Influence & 0.451 & 0.204 & 0.200 & $<0.0001^{* * *}$ \\
Personal Attributes & 0.201 & 0.051 & 0.049 & $<0.0001^{* * *}$ \\
Peer Group & 0.187 & 0.035 & 0.033 & $<0.0001^{* * *}$ \\
Sect of Candidate & 0.081 & 0.018 & 0.017 & $<0.0001^{* * *}$ \\
Political Campaign & 0.026 & 0.010 & 0.009 & $<0.0001^{* * *}$ \\
Sympathy (candidate) & 0.044 & 0.002 & 0.001 & $>0.05$ (ns) \\
Experience in politics & 0.008 & 0.001 & 0.001 & $>0.05(\mathrm{~ns})$ \\
\hline
\end{tabular}

Simple linear regression analysis was run to explain voting behavior. The predictors include eight variables. The regression model fulfilled all the basic assumptions to run the model. The findings of the study revealed that $B a r a d r$ (caste group) $(\beta=.84, p<.001)$, Family influence $(\beta=.45$, $\mathrm{p}<.001)$, Personal attributes $(\beta=.20, \mathrm{p}<.001)$, Peer $(\beta=.18, \mathrm{p}<.001)$, Sect $(\beta=.08, \mathrm{p}<.001)$, Political campaign $(\beta=.02, \mathrm{p}<.001)$, Sympathy $(\beta=.04, \mathrm{p}<.001)$, Experience $(\beta=.00, \mathrm{p}<.001)$. Findings pointed out that Baradri and Family influence explained $\mathrm{R}^{2}=.718$ and $\mathrm{R}^{2}=.20$ respectively however, two variables sympathy and experience were not significant. 


\section{Discussion}

Research in hand looked at different factors predicting how different people cast their votes in rural areas of Punjab, Pakistan. Voting behavior research has established that in modern democracies economic conditions, political party affiliation, ethnic identity, the capability of the candidate, campaign, and personality are counting more (Campbell, Converse, Miller \& Strokes, 1964; Rock \& Baum, 2010). And generally, people decide to vote rationally, evaluating their benefits within the preferred range. The results suggested that the overall $72 \%$ variance in voting behavior is vindicated only by Baradri (caste group) and family. Interestingly, the experience of the candidate within politics and sympathetic consideration for the candidate was not statistically significant.

Research also highlighted that personal attributes of contesting candidate, peer suggestions to caste vote, the religious identity of these candidates (sect), and political campaign for election were not very significant in explaining variation in voting behavior in the study area. These findings very clearly elucidate that in rural social organization the individual is less important and significant in his socio-cultural environment. His social ties i.e. friends are less significant and play a little role during the election. The political campaigns also play very role. This finding is in accordance with the previous scholarship that highlights that in rural areas the political campaign plays a very little role (Sheikh, Bokhari \& Naseer, 2015). Religious affiliation or identity is a very important and deciding factor in politics in rural areas of Punjab (Bashir \& Khalid, 2019). However, findings of this research do not correspond to the previous scholarship on voting in rural Punjab. Religious support, an affiliation of sect does not play a very significant role in this research. The only explaining factors are caste group and family that overall count of $72 \%$ of the variation in voting behavior.

In rural areas, people prefer their socio-cultural ties based on blood and ancestry. The commonality of language, caste, and lineage put pressure upon the voters while deciding their votes (Bashir \& Khalid, 2019). Voters considered the caste group an important factor while voting over other factors like a political party, candidate profile, and political agenda (Muhammad \& Hassan, 2016). It can be concluded that the sociological school of thought is justifying to voters to cast the vote. Psychological theory helps very little in influencing voters in the study area. However, it can also be argued that voters choose rationally the caste group as they still believe that whatever the political benefits maybe, association with caste group is more satisfying, paying, and long-lasting. Strong social ties with family and caste groups in-turn, ensure the political and social benefits for them.

\section{Conclusion}

This research article tested social, cultural, demographic, political, and psychological factors derived from theoretical perspectives to see which factor/s explained the best voting behavior in rural areas in Punjab. Based on the data, it is concluded that rural voters evaluate different social, cultural, demographic, political and psychological factors when deciding to vote and found sociological factors more influencing and effective.

\section{References}

Ahmed, A., Chaudhry, A. G., \& Hussain, S. (2013). Educated Youth, Role of Biradarism and Local Politics: An Anthropological Analysis of Students of PMAS-Arid Agriculture University Rawalpindi, Pakistan. International Journal of Educational Science and Research (IJESR), 3, 21-26.

Akhter, Z., \& Sheikh, Y. A. (2014). Determinants of Voting Behaviour in India: Theoretical Perspective. Public Policy and Administration Research, 4(8), 104-109.

Andolina, Molly W., Krista Jenkins, Cliff Zukin, and Scott Keeter. (2003). "Habits from Home, Lessons from School: Influences on Youth Civic Development." PS: Political Science and Politics, 36(2): 275-80.

Andersen, R., \& Heath, A. (2003). Social Identities and Political Cleavages: the Role of Political Context. Journal of the Royal Statistical Society: Series A (Statistics in Society), 166(3), 301327.

Andrew, R. W. (1999). The Pakistani Voter: Electoral Politics and Voting Behavior in the Punjab. Karachi: Oxford University Press.

Arrow, K. J. (1986). Rationality of self and others in an economic system. Journal of Business, S385S399. 
Askari, H. R. (2002). Election Campaign: Need for Reform. In M. Waseem (Ed), Electoral Reform in Pakistan (141-160). Islamabad: Friedrich Ebert Stiftung.

Bashir, U., \& Khalid, I. (2019). Religion and Electoral Politics in Punjab: A Case Study of 2018 General Elections. South Asian Studies, 34(1), 7-24.

Bartels, L. M. (2002). The Impact of Candidate Traits in American Presidential Elections. In A. King (Ed.), Leader's Personalities and the Outcome of Democratic Elections (pp. 44-69). Oxford, UK: Oxford University Press.

Bike, W. S. (2012). Winning Political Campaigns: A Comprehensive Guide to Electoral.

Campbell, A., Converse, P., Miller, W., \& Stokes, D. (1960). The American Voters. New York: Wiley.

Carras, M. C. (1987). [Review of Caste, Faction \& Party in Indian Politics. Vol. 1, Faction Party]. The Annals of the American Academy of Political and Social Science, 491, 173-175.

Dalton, R. J., Burklin, W. P., \& Drummond, A. (2001). Public opinion and direct democracy. Journal of Democracy, 12(4), 141-153.

Dubois, E. (2007). Les determinants économiques du vote 1976-2006: trente ans de fonctions de vote en France. Revue d'économie politique, 117(2), 243-270.

Heywood, A. (2002). Politics. (2nd ed.). New York: Palgrave.

Huckfeldt, Robert, and John Sprague. (1991). Discussant Effects on Vote Choice: Intimacy, Structure, and Interdependence. Journal of Politics, 53 (February): 122-58.

Kanwal, L., Shahid, A. R., \& Naeem, M. (2016). Voting Behavior of Educated Youth in Pakistan: A Study of Multan City. Journal of the Research Society of Pakistan, 53(2), 90-104.

Kurtbaş, İ. (2005).The Factors Influencing Voting Preferences in Local Elections "An Empirical Study". Latino Voting Behavior. J. Political Marketing 4 (4).

Lazarsfeld, P. F., Berelson, B., \& Gaudet, H. (1944). The people's choice: How the voter makes up his mind in a presidential election. New York: Duell, Sloan and Pearce.

Lewis-Beck, M. S., \& Stegmaier, M. (2008). The economic vote in transitional democracies. Journal of Elections, Public Opinion and Parties, 18(3), 303-323.

McClurg, Scott D. (2004). Indirect Mobilization: The Social Consequences of Party Contacts in an Election Campaign. American Politics Research 32 (July): 406-43.

Mughees, A. (2006). Caste System in the Sub-Continent. Al-Siyasa-A Journal of Politics, Society and Culture, 30.

Muhammad, H. J., \& Hasan, S. S. (2016). Development of the Decision to Vote Scale. Pakistan Journal of Social and Clinical Psychology, 14(2), 10-14.

Naurin, E. (2011). Election promises, party behaviour and voter perceptions. Springer.

Persson, T., \& Tabellini, G. E. (2002). Political economics: explaining economic policy. MIT press.

Rajesh Dev. (1999). General Elections 1996, 1998: Community Loyalties and Regional Outlook. Economic and Political Weekly, 34(34/35), 2481-2485.

Robinson, John P. (1976). Interpersonal Influence in Election Campaigns: Two Step-Flow Hypotheses. Public Opinion Quarterly, 40 (summer): 304-19.

Rock, E., \& Baum, L. (2010). The Impact of High-visibility Contests for U.S. State Court Judgeships: Partisan Voting in Nonpartisan Elections. State Politics and Policy Quarterly, 10, 368-396.

Rumi, Raza. (2009). Casteism; Alive and Well in Pakistan (Punjab). The Friday Times Lahore, Pakistan, February $15^{\text {th }}$.

Sarlamanov, K., \& Jovanoski, A. (2014). Models of Voting. Researchers World, 5 (1), 16.

Sekhon, J. (2000). Modern India. Boston: McGraw-Hill.

Shaheen, G. (2004). The Elections 2002 in Pakistan, A step Towards Stable Democracy. MA Thesis, Political Science Department, University of the Punjab, Lahore.

Shahwar, D. \& M. Asim. (2012). Voting Behavior of People towards Different Political Parties in District Faisalabad, Pakistan. Mediterranean Journal of Social Sciences. 3(2):85-91.

Sheikh, J. A., Bokhari, S. S., \& Naseer, M. R. (2015). Voting Behavior and Elections in Pakistan (A Case Study of Pakistani Election Methods and Methodology). Journal of Social Sciences, 449-456. 
Shin, J. H., \& Lee, H. (2017). Legislative Voting Behaviour in the Regional Party System: An Analysis of Roll-Call Votes in the South Korean National Assembly, 2000-8. Government and Opposition, 52(3), 437-459.

Smith, C. A., \& Smith, K. B. (2000). A Rhetorical Perspective on the 1997 British Party Success. Central Park Communications, Inc.

Torney-Purta, J. (1992). Cognitive representations of the political system in adolescents: the continuum from pre-novice to expert. New directions for child development, 56, 11-25.

Trent, J. S., \& Friedenberg, R. V. (2008). Political campaign communication: Principles and practices. Rowman \& Littlefield.

Usman, A., Munawar, R., \& Amjad, A. (2013). Determinants of Effective Electoral Campaign. South Asian Studies, 28(1), 107.

Verba, Sidney, Kay L. Schlozman, \& Henry E. Brady. (1995). Voice and Equality: Civic Voluntarism in American Politics. Cambridge, MA: Harvard University Press.

Weiss, M. L. (2009). Edging toward a new politics in Malaysia: Civil society at the gate? Asian Survey, 49(5), 741-758.

Wilder, A. R. (1999). The Pakistani Voter: Electoral Politics and Voting Behavior in the Punjab. Karachi: Oxford University Press. 